\title{
Life cycle environmental impacts of a prospective palm-based biorefinery in Pará State-Brazil
}

\author{
Mitra Kami Delivand*, Edgard Gnansounou \\ Bioenergy and Energy Planning Research Group, École Polytechnique Fédérale de Lausanne (EPFL), Station 18, CH-1015 Lausanne, Switzerland
}

\section{H I G H L I G H T S}

- Two million tons FFB produces $340 \mathrm{kt}$ biodiesel, $39 \mathrm{kt}$ bioethanol, and $268 \mathrm{GWh}_{\mathrm{el}}$.

- $7.5 \mathrm{t} \mathrm{CO}_{2}$-eq/ha yr sequestrations by oil palm reforesting lands in the N-Brazil.

- A positive life cycle energy balance of the biorefinery.

- Life cycle GHG reductions of $77-79 \%$ and $84-89 \%$ for biodiesel and bioethanol.

\section{A R T I C L E I N F O}

\section{Article history:}

Available online 30 July 2013

\section{Keywords:}

Palm-based biorefinery

Life cycle assessment

Direct land-use change

\begin{abstract}
A B S T R A C T
The availability of about 18 million hectares of grassland in Pará State, Brazil, and the possibility of increasing the livestock density display a good perspective for the oil palm expansion in pasture land. A life cycle assessment is performed for a prospective palm-based biorefinery to view two regional and one global environmental impact and the consequences of the land-use change in terms of GHG emissions. Oil palm cultivation in an area of $\sim 110,000$ hectares of land can annually produce $\sim 39,000$ tons of bioethanol, $\sim 340,000$ tons of biodiesel, $\sim 268 \mathrm{GW}$ h net electricity and other co-products. The life cycle GHG emissions reduction for biodiesel and bioethanol as compared to fossil diesel and gasoline would be $76.9-79.3 \%$ and $83.7-88.6 \%$. The advantage of grassland rehabilitation by oil palm plantation is the removal of $\sim 188 \mathrm{t}$ $\mathrm{CO}_{2} /$ ha from the atmosphere during the plant lifetime. The entire inflows and outflows for the conversion processes are schemed.
\end{abstract}

() 2013 Elsevier Ltd. All rights reserved.

\section{Introduction}

In Brazil, the transportation sector consumed around 32\% (74.2 million tons petroleum equivalent) of the total final consumption of energy in 2011. The use of biofuel for transportation is the target of Brazil. Biodiesel is recognized as environment-friendly alternative fuels for the transportation fleet. While several studies have investigated the environmental impacts of the whole process chains of biofuel production and concluded a positive fossil fuels savings and GHG reductions (Kim and Dale, 2005; Liang et al., 2013), some others have concluded differently when considering other environmental impacts and land-use change (Gnansounou et al., 2009; Singh et al., 2010; Hassan et al., 2011).

The expansion of biofuels could cause potential impacts on the water consumption, land- use, socio-economic aspects and other environmental consequences. In fact, the sustainability conditions could be the limiting factors to the realization of higher blends of biofuels (Gnansounou et al., 2009). It is expected that these

\footnotetext{
* Corresponding author. Tel.: +412169336217.

E-mail addresses: mkk1384@yahoo.com, mitra.kami@epfl.ch (M. Kami Delivand).
}

limitations can be partially overcome by integrating a second generation biofuel and a spectrum of co-products generation (Cherubini and Strømman, 2011).

The emerging lignocellulosic biorefinery system to integrate biomass conversion processes and equipment to co-produce bioenergy and chemicals from biomass seems to be promising in gaining additional environmental benefits and sustainable bio-based resources (Cherubini and Strømman, 2011). For achieving the multi-functionality of the biorefinery, the complex structure of lignocellulosic biomass needs to be fractionated by appropriate pretreatments FitzPatrick et al. (2010). The most promising biorefinery system uses a mix of biomass feedstock and yields an array of products by integrating combination of technologies (Luo et al., 2010). The oil palm fruit can be considered as one of the promising feedstock for biorefinery since it contains $67-84 \%$ carbohydrate and $15-33 \%$ lignin in the empty fruit bunch (EFB) for the second generation bioethanol, chemicals and heat and power, $44-45 \%$ triglycerides in the mesocarp of the palm fruit (Chew and Bhatia, 2008) for the first biodiesel generation, and considerable amount of other mixed residues that can be valorized.

This study intends to scheme the whole process of using oil palm fruit in a scaled biorefinery system and to determine the 
life-cycle inventories and consequent environmental impacts of the system taking into account the land-use change of natural grass areas to the cultivation of oil palm in Brazil. The integrated thermo-mechanical, thermo-chemical, and biochemical conversion processes into the system results in the production of biodiesel, bioethanol, and other co-products.

According to the Brazilian Institute of Geography and Statistics (IBGE), 99\% of the palm oil farms (accounting for only 54,000 ha of land) are concentrated in few regions of Pará. In this state, the total permanent crop land, as of 2011, is 255.3 thousand-ha (including oil palm farms), the temporary crop occupation is around 796 thousand-ha, and a large proportion of about 18 million-ha of land is occupied by the grass/pasture. Pará is the second state in the region with the highest deforested land-use for pastures. Given that the Pará State currently has around 18 million ha of land in pasture, and the possibility of increasing the livestock density from $1.08 \mathrm{head} / \mathrm{ha} / \mathrm{yr}$ to $2.7 \mathrm{head} / \mathrm{ha} / \mathrm{yr}$, considerable land areas could be allocated to oil palms cultivation. Table 1 shows the potential of land availability for oil palm expansion in 20 regions of Pará State as an example.

\section{Methodologies}

Palm-based biorefinery is a multi-processing system in which the biomass is converted to a variety of products. Depending on the conversion pathways, the life cycle inventory and the environmental impacts associated with a prospective palm oil-based biorefinery plant in Pará State, Brazil are quantified. The inventory is carried out following the instruction of ISO 14040 and 14044. The main goal is to assess the major environmental and direct landuse change impacts associated with products and co-products from the palm Fresh Fruit Bunch (FFB) in a biorefinery plant in Brazil. The scope comprises from the oil palm plantation until the products and co-products at the end of the biorefinery gate and combustion of the
Table 1

The potential availability of oil palm on the basis of an increased livestock density.

\begin{tabular}{llll}
\hline Municipality & $\begin{array}{l}\text { Current area } \\
\text { oil palm (ha) }\end{array}$ & $\begin{array}{l}\text { Current pastures } \\
(\text { ha })^{\mathrm{a}}\end{array}$ & $\begin{array}{l}\text { Potential land } \\
(\text { ha })^{\mathrm{b}}\end{array}$ \\
\hline Açará & 7000 & 10,823 & 6493 \\
Bonito & 4200 & 11,325 & 6795 \\
BreuBranco & - & 119,702 & 71,821 \\
Bujaru & 300 & 6475 & 3885 \\
Concórdia do Pará & 2000 & 8500 & 5100 \\
Castanhal & 1000 & 25,370 & 15,222 \\
Igarapé-Açú & 4200 & 17,638 & 10,583 \\
Moju & 7093 & 39,351 & 23,611 \\
Inhangapi & 16 & 11,759 & 7055 \\
Maracanã & 100 & 2491 & 1495 \\
Nova timboteua & 96 & 12,900 & 7740 \\
Santa Bárbara do Pará & 200 & 576 & 346 \\
Santa Isabel do Pará & 400 & 16,569 & 9941 \\
Santo Antônio do Tauá & 2900 & 5000 & 3000 \\
Santa Maria do Pará & 350 & 13,251 & 7,951 \\
São Francisco do Pará & 270 & 11,212 & 6727 \\
Tailândia & 20,893 & 77,614 & 46,568 \\
Terra Alta & 100 & 3533 & 2120 \\
Tomé & 2600 & 100,198 & 60,119 \\
Vigia & 250 & 3773 & 2264 \\
Total & 53,968 & 498,060 & 298,836
\end{tabular}

a Source of the land areas from the Brazilian Institute of Geography and Statistics (IBGE).

b Palm oil credit land in case of increasing the livestock density (www.amazonia.org.br).

biofuel blends in ordinary passenger cars. For comparison purposes, the life-cycle well-to-wheel GHG emissions of the combustion of palm-based biofuels will be compared with the combustion of comparative fossil-based fuels. As the biorefinery receives and processes FFB as the initial feedstock, the functional unit used throughout the study is 1 tons of FFB for the well-to-tank environmental impact assessment. Alternatively, for the well-to-wheel GHG emissions of biofuel, a traveled distance of $100 \mathrm{~km}$ is used as the functional unit.

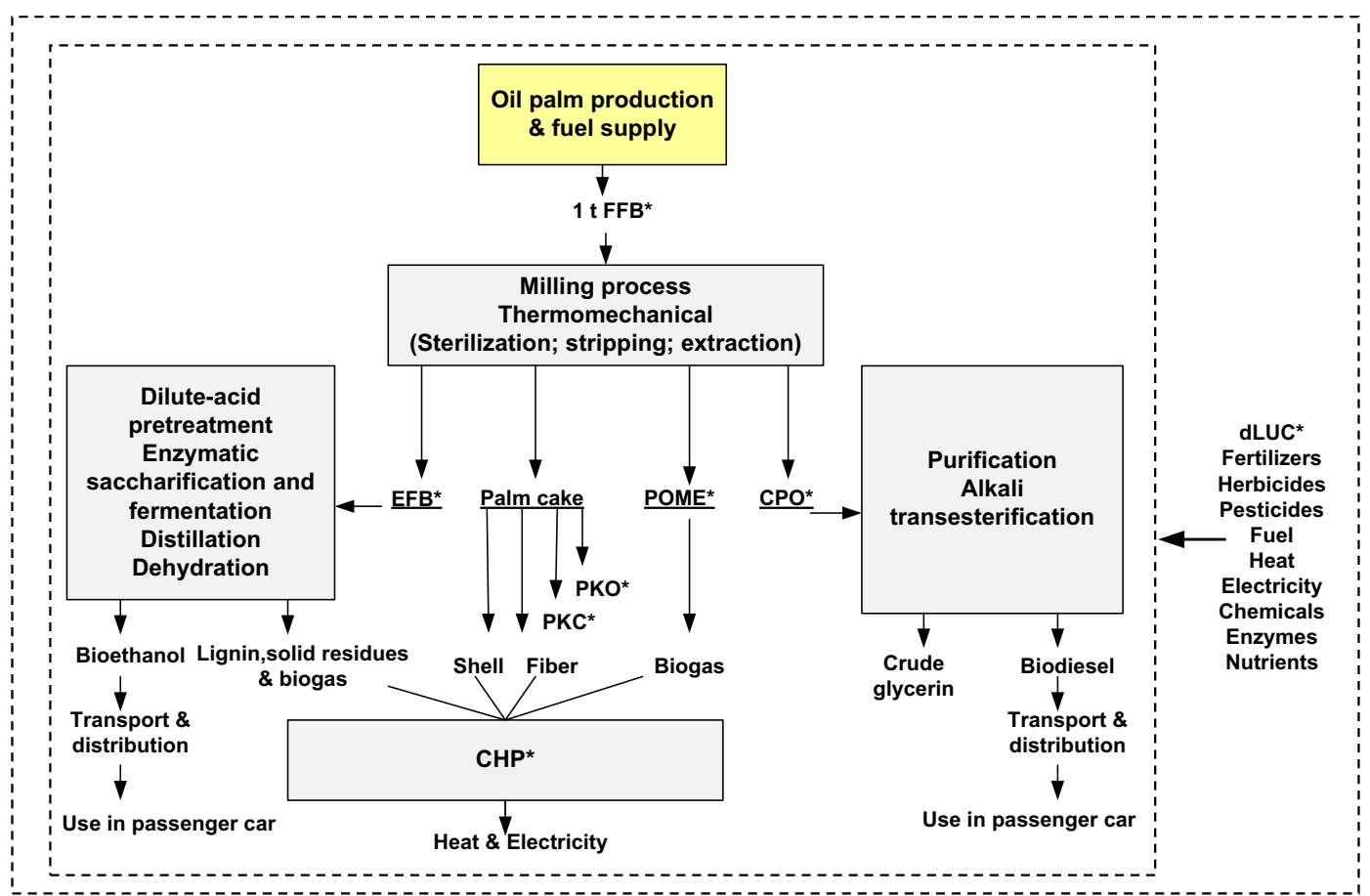

*dLUC: Direct Land Use Change; FFB: Fresh Fruit Bunch; EFB: Empty Fruit Bunch; POME: Palm Oil Mill Effluents; CPO: Crude Palm Oil; PKO: Palm Kernel Oil; PKC: Palm Kernal Cake; CHP: Combined Heat and Power Plant.

Fig. 1. System boundary of oil palm to biofuels and bioproducts. 
The life-cycle palm oil biorefinery consists of various processes. The first process is the agricultural process (land preparation, plantation, maintenance), followed by FFB collection and transportation, milling process, the transesterification of oil for producing biodiesel, and finally the pretreatment, enzymatic hydrolysis and fermentation of the EFB to produce bioethanol. The system boundary used in this study is shown in Fig. 1. The life-cycle inventory is obtained from Ecoinvent v2.2 for all inputs and outputs to and from the system boundary in Fig. 1 as explained in the following sections. The life-cycle inventory of enzymes is from (Nielsen et al., 2007). CML2 method available in Ecoinvent v2.2 is used, and direct landuse change impacts is assessed through the methodology provided in the 'Guideline for National Greenhouse Gas Inventories' by the Intergovernmental Panel on Climate Change (IPCC, 2006). The detailed input data and assumptions for each of the process chains are explained in the following sections.

The GHG emissions of the biofuels will be compared to the alternative conventional fossil-fuels as well as to the emissions of soybean-based biodiesel and sugarcane-based bioethanol, the two top-listed biofuels in Brazil.

\subsection{Feedstock supply chain}

The productivity of the feedstock, its physical characteristics, and harvesting practices are important factors in determining the transportation distances. According to the Brazil Agrianual-Agra FNP, depending on the crop age, the oil palm productivity presented as $\mathrm{t} F \mathrm{FB} / \mathrm{ha}$, varies between 7 and 25 tons during the 25 years commercial life time of the oil palm. Thus, the weighted average yield of FFB is around 18 tons/ha. Harvest is performed manually by using appropriate devices (e.g., sickles with long aluminum pole) and it occurs throughout the year; though, it is intensive between October and January. The fruit bunches must be processed within $24 \mathrm{~h}$ after harvesting to prevent the fruit acidification, and this is the main reason that the conversion plant should be close to the plantation area. In general, the catchment area from which the FFB can be collected depends not only on the annual demand of the plant, and yield, but also on the fraction of the land which is used for other purposes, e.g., infrastructures, water bodies, other farmlands, or legal reservation. The following equations adopted from (Delivand et al., 2011) are used to estimate the catchment area and road transportation distance for the FFB's supply assuming that the biorefinery plant is located in the centre of the catchment area.

Catchment area $($ ha $)=\frac{\text { Oil palm cultivation area }}{\text { land availability fraction } \times(1 \text {-other farms fraction })}$

Roundtrip distance $(\mathrm{km})=\sqrt{0.01 \times \text { Catchment area } / \mathrm{Pi}} \times 1.14 \times 2$

In Eq. (1), it is assumed that $25 \%$ of land is used for infrastructures (roads, villages, water bodies, etc), thus, the land availability fraction in Eq. (1) could be 75\%. Furthermore, since the focus is on the oil palm and grass growing areas, it is assumed that within the collection area, $50 \%$ of land is used for pastures or other legal reservations. In Eq. (2), 'Pi', and constant figures '0.01', '1.14', and ' 2 ' are the ratio of the circle's circumference to its diameter $(\sim 3.14)$, conversion unit of hectare to square kilometer, the road winding factor, and round trip factor, respectively.

It is also important to study the farm size, because it indicates the number of the local farmers/stakeholders who are directly involved in the feedstock supply chain. According to the IBGE statistics, the farm size categories of Pará State in 2006 are as follows: $31 \%$ for the farm size less than 10 ha, $45 \%$ for the farm size between
10 and 100 ha, $1 \%$ for the farm size bigger than 1000 ha, and the rest for the farm size between 100 and 1000 ha. Therefore, the majority of the farm sizes are between 10 and 100 ha. Nevertheless, the recognition of the land ownership rights in Pará State is complex leading to uncertain situations in long term sustainable economic activities.

On the basis of the current and future land availability of oil palm farms in Table 1, and the above discussions, an approximate oil palm cultivation area of 110,000 ha producing about 2 million tons of FFB/yr is the assumed scale in this study. Accordingly, the round-trip road transportation distance obtained from Eq. (1) and Eq. (2) would be $\sim 86 \mathrm{~km}$. Road transportation of the collected FFB to the mill is performed by the heavy truck with a practical loading capacity of 5-10 t FFB/trip (averagely $8 \mathrm{t} \mathrm{FFB/trip).} \mathrm{Assum-}$ ing a fuel efficiency of $0.35 \mathrm{l} / \mathrm{km}$ for the truck, the diesel consumption is estimated to be $0.043 \mathrm{l} / \mathrm{t} / \mathrm{km}$ or 3.671 diesel/t FFB.

\subsection{Plantation and maintenance of oil palm}

Oil palm (Elaeis guineensis) is a tropical tree crop and its optimal growth is due to a high yearly rainfall of $1800-2000 \mathrm{~mm}$, stable high temperature ranging between $24^{\circ} \mathrm{C}$ and $28^{\circ} \mathrm{C}$ (minimum temperature higher than $18^{\circ} \mathrm{C}$ ), well drained and deep soil with $\mathrm{pH}$ ranged between 4 and 6 , flat terrains with slope less than $7 \%$, and implication of fertilizers, pesticides, and disease controls.

The establishment of commercial oil palm requires some preparations such as topographic surveys, selection of the plantation area, land cleanings, and road constructions. Plantation of legume vegetation, generally Pueraria javanica, can control the emergence of weeds, protect the soil erosions, fix nitrogen in the ground, retain soil moisture, and promote the soil remediation. The life span of commercial oil palm crops is almost 25 years including 11-12 months pre-nursery and nursery stage, $2-3$ years immature phase, and almost 22 years mature phase. During the life cycle of the crop, fertilization must occur regularly.

Seedlings are carried out in poly plastic bags of $38 \times 45 \mathrm{~cm}^{2}$ in triangular arrangements of $0.75 \times 0.75 \times 0.75 \mathrm{~m}^{3}$ (centre to centre). On average, 300 seeds for 143 plants/ha are required. As stated in the Brazilian Agricultural Research Corporation-Embrapa, the soil of the Amazon region is somehow poor to provide the nutrients for oil palms. The fertilizers required for oil palm nursery and maintenance in Table 2 depend on soil types of the region where oil palm is planted.

Table 3 outlines the nutrient content of Empty Fruit Bunches (EFB) and Palm Oil Mill Effluents (POME) if recycled into the field

Table 2

The outlined chemical fertilizers required for palm oil nursery and maintenance ${ }^{\mathrm{a}}$.

\begin{tabular}{lll}
\hline Input-age & Unit & Quantity \\
\hline Mixture ${ }^{\mathrm{b}}-1-3$ months & $\mathrm{g} /$ mixture/seed & 5 \\
Mixture - 4-6 months & & 10 \\
Mixture - 7-9 months & & 15 \\
Mixture - 10-13 months & & 20 \\
$\mathrm{~N}^{\mathrm{c}}-0-4$ yr \& onwards & g/plant & $150,200,250,300,400$ \\
$\mathrm{P}^{\mathrm{d}}-0-4$ yr \& onwards & & $400,600,800,1000,1150$ \\
$\mathrm{~K}^{\mathrm{e}}-0-4$ yr \& onwards & & $150,300,600,1000,1200$ \\
Mg $^{\mathrm{f}}-0-4$ yr \& onwards & & $150,200,250,300,350$ \\
Borax - 0-4 yr \& onwards & & $25,50,75,100,110$ \\
\hline
\end{tabular}

a The Brazilian Agricultural Research Company-Embrapa, and direct data collection in 2013.

${ }^{b}$ Mixture: $\left.3 \mathrm{~kg} \mathrm{~N}\left[71 \%\left(\mathrm{NH}_{4}\right)_{2} \mathrm{SO}_{4}, 18 \% \mathrm{NH}_{4} \mathrm{NO}_{3}, 11 \% \mathrm{NH}_{4} \mathrm{Cl}\right)\right], 4 \mathrm{~kg} \mathrm{P}$ (phosphate rock as $\left.\mathrm{P}_{2} \mathrm{O}_{5}\right), 1 \mathrm{~kg}\left(\mathrm{~K}_{2} \mathrm{O}\right)$, and $2 \mathrm{~kg}\left(\mathrm{MgSO}_{4}\right)$.

c Urea with $32 \%$ of $\mathrm{N}$.

d Triple superphosphate with $45 \% \mathrm{P}_{2} \mathrm{O}_{5}$.

e Potassium chloride with $60 \% \mathrm{~K}_{2} \mathrm{O}$.

f Magnesium sulfate with $16 \% \mathrm{Mg}$. 
Table 3

Major nutrient contents of EFB and POME.

\begin{tabular}{lll}
\hline Elements & $\mathrm{kg} / \mathrm{t}_{\text {fresh EFB }}{ }^{\mathrm{a}}$ & $\mathrm{kg} / \mathrm{l} \mathrm{POME}^{\mathrm{b}}$ \\
\hline $\mathrm{N}$ & 3.27 & 0.00070 \\
$\mathrm{P}$ & 0.25 & 0.00045 \\
$\mathrm{~K}$ & 7.96 & 0.00171 \\
$\mathrm{Mg}$ & 0.53 & 0.00052 \\
\hline
\end{tabular}

a Adjusted for moisture content and adobpted from (Baharuddin et al., 2010).

b Average values obtained from (Baharuddin et al., 2010; Nwoko and Ogunyemi, 2010).

as fertilizers (Queiroz et al., 2012); it is assumed that 20\% of the nutrient estimates in Table 3 are lost due to the leaching and volatilization.

For the herbicides and pesticides, an average amount of Carbamate pesticide, and Glyphosfate and Paraquat herbicides are $1.35 \mathrm{~kg} / \mathrm{ha}, 3.87 \mathrm{~kg} / \mathrm{ha}$ and $3.60 \mathrm{~kg} / \mathrm{ha}$, respectively (Pleanjai and Gheewala, 2009).

Another consideration is the possibility of more chemical fertilizer applications due to the oil palm expansion in the grass lands. Not very precise data is available in the literature, however, it is stated that palm oil yield would be lower by $10 \%$, when grass lands are changed to oil palm (Hassan et al., 2011) compared to a case without land conversion. On this basis, this study has considered extra fertilizers which could be required to compensate for the reduced productivity if oil palm is expanded in grass lands.

In case of the transportation of chemical fertilizers, it is assumed that they are imported from Europe and shipped for an approximate distance of $8500 \mathrm{~km}$ to Brazilian ports by oceanic freight ships. Then, heavy trucks with a loading capacity of $16 \mathrm{t}$ for the road system of Brazil are delivering the chemicals within an average distance of $150 \mathrm{~km}$. This is in compliance with the transport scenario stated by (Queiroz et al., 2012).

\subsection{Milling process}

In the milling process a substantial amount of co-products are generated (Patthanaissaranukool et al., 2013), see Fig. 1. The milling capacity is around $230 \mathrm{t} \mathrm{FFB/h}$. FFB is sterilized by cooking for about $70-90 \mathrm{~min}$ at $120-130^{\circ} \mathrm{C}$ using steam to deactivate the production of Free Fatty Acid through lipolytic enzyme, it also facilitates the stripping of the fruits from bunches and the oil extraction. The separated fruits from FFB after stripping (threshing) are mashed under steam heated conditions; the oil mash from the digester is pushed through the screw presser, vibrating screen, hydro cyclone, and decanter to separate the oil from cake; the purification of the oil is performed by centrifugation and vacuum driers at an assumed conversion efficiency of $\sim 87 \%$. The fiber and nuts are separated in a cyclone, and the nuts are cracked in a centrifugal cracker to separate kernels and shells.

The fibers ( $40 \%$ moisture content, and $8.4 \%$ ash), and shells ( $\sim 10 \%$ moisture content, and $3.2 \%$ ash) with low heating values (wet basis) of $10 \mathrm{MJ} / \mathrm{kg}$ and $18.5 \mathrm{MJ} / \mathrm{kg}$, respectively are fed into the integrated biomass fired CHP plant (see Section 2.5 for the description of the CHP plant). Kernels are sent into the kernel oil extraction processes. The average unit mass of products in the FFB milling process is obtained from literature (Pleanjai and Gheewala, 2009; Hassan et al., 2011; Queiroz et al., 2012; Patthanaissaranukool et al., 2013) that is $240 \mathrm{~kg} \mathrm{EFB}, 203 \mathrm{~kg}$ CPO, $143 \mathrm{~kg}$ fibers, $54 \mathrm{~kg}$ kernels, $67 \mathrm{~kg}$ shells, and $548 \mathrm{~kg}$ POME. POME is a mixture of polluted effluent with high COD concentration of $0.40 \mathrm{~kg} / \mathrm{l}$, which is digested anaerobically to produce about $15 \mathrm{~m}^{3}$ biogas (at atmospheric pressure) $/ 1 \mathrm{~m}^{3}$ POME (Patthanaissaranukool et al., 2013). The biogas $\left(\sim 65 \% \mathrm{CH}_{4}, 22 \mathrm{MJ} / \mathrm{m}^{3}\right)$ is fed in the CHP plant.
The average input electricity and steam in this process is $18.06 \mathrm{kWh} / \mathrm{t} \mathrm{FFB}$, and $1400 \mathrm{MJ} / \mathrm{FFB}$, respectively (Pleanjai and Gheewala, 2009).

\subsection{Biodiesel production process}

After the purification of the oil by centrifugation and vacuum driers, the biodiesel production is performed through transesterification known as the most common methods used to reduce oil viscosity and its conversion to the corresponding fatty acid in the presence of a catalyst and an alcohol. Methanol is commonly used in biodiesel production and sodium hydroxide is widely used as the catalyst because of its high productivity and low costs.

The conversion of the palm oil via alkali catalytic methanol transesterification offers the most interesting path with faster reaction kinetics (Chew and Bhatia, 2008) to produce methyl ester and crude glycerin. The optimum condition for the continuous process depends on the molar ratio of alcohol to oil, temperature of the reaction, catalyst amount and the stirring. Complete settling of the crude glycerol at the bottom will occur within 20-24 h. Glycerol is a co-product that can be used as raw materials in other industries (Wei et al., 2011). The crude methyl ester stream is washed with water at $\mathrm{pH} 4.5$ to neutralize the catalyst, and is followed by centrifugation and vacuum dryer to produce purified methyl ester (Haas et al., 2006) at an average conversion efficiency of $97 \%$ biodiesel (Haas et al., 2006; Harding et al., 2008).

For the transesterification process, an average amount of $8.6 \mathrm{kWh}$ electricity, $1820 \mathrm{~kg}$ steam, $10.2 \mathrm{~kg} \mathrm{NaOH}, 110.0 \mathrm{~kg}$ methanol, $31.8 \mathrm{~kg}$ water, and $34.0 \mathrm{~kg}$ hydrochloride acid are main input materials and energy in the alkali transesterification process to generate $1000 \mathrm{~kg}$ Biodiesel (from 5.87 t FFB) (Haas et al., 2006; Harding et al., 2008).The produced biodiesel is used in diesel engine vehicles at the gas station. It is estimated that biodiesel is transported and distributed by 28-t trucks to the refinery and in gas stations at an average distance of $800 \mathrm{~km}$ and $200 \mathrm{~km}$, respectively.

\subsection{Bioethanol production process}

EFB produced from the milling process of FFB is an ideal biomass for ethanol production because of its high content of carbon (49 wt\%), hydrogen ( $7 \mathrm{wt} \%$ ), and oxygen (36 wt\%). It consists of carbohydrates such as glucan and xylan in high concentrations of $35-50 \%$ and $10-20 \%$, respectively (Jung et al., 2013). Ethanol production from lignocellulosic feedstock is elaborately studied by the US National Renewable Energy Laboratory (NREL) (Aden et al., 2002). This study has considered the same process design and conversion efficiencies of Aden et al. (2002) in which dilute sulfuric acid is used for the pretreatment of EFB followed by the enzymatic hydrolysis of the pretreated EFB, and simultaneous saccharification and fermentation with recombinant Zymomonas mobilis bacterium to produce $\sim 99.5 \%$ purified ethanol using vapor-phase molecular sieve adsorption. The process condition is summarized in Table 4.

Apart from the treatment method and conversion processes, feedstock composition significantly affects the ethanol yield. In this study, the average dry weight percentage of the EFB components are $29.6 \%$ glucan, $18.8 \%$ xylan, $0.6 \%$ galactan, $1.2 \%$ arabinan, $0.2 \%$ mannan, $1.5 \%$ acetyl group, $16.9 \%$ extractives, $22.9 \%$ lignin, and $5.4 \%$ ash (Chiesa, 2012). The average moisture content of EFB is 62\% (Baharuddin et al., 2010). The yield of EFB-to-ethanol on the basis of the EFB composition and NREL's conversion efficiencies in Table 4 (Aden et al., 2002) would be $214.7 \mathrm{~kg}$ ethanol $/ \mathrm{t} \mathrm{EFB}(\mathrm{dry})$.

The purpose of the integration of Combined Heat and Power (CHP) subsystem is to burn the residues and produce steam processing and electricity. It consists of combustor, and multistage turbine and generator. The turbine has extraction ports to allow the superheated steam leave the boiler and be used in the 
Table 4

Summarized process conditions of EFB to ethanol (Aden et al., 2002).

\begin{tabular}{|c|c|c|}
\hline Pretreatment condition & & Reactant and converted fraction \\
\hline Sulfuric acid concentration & $1.1 \%$ & $90 \%$ of xylan to xylose $7 \%$ of glucan to glucose \\
\hline Residence time & $2 \min$ & \\
\hline Temperature & $190^{\circ} \mathrm{C}$ & \\
\hline Solid concentration & $30 \%$ & \\
\hline Hydrolysis or saccharification condition & & Reactant and converted fraction \\
\hline Initial solid concentration & $20 \%$ & $90 \%$ of glucan to glucose \\
\hline Temperature & $65^{\circ} \mathrm{C}$ & \\
\hline Residence time & 1.5 days & \\
\hline Cellulase loading & $12 \mathrm{FPU}^{\mathrm{a}}$ & \\
\hline Co-fermentation ${ }^{\mathrm{b}}$ condition & & Reactant and converted fraction \\
\hline Organism & Z. mobilis & $95 \%$ of glucose to ethanol $85 \%$ of xylose to ethanol \\
\hline Temperature & $41^{\circ} \mathrm{C}$ & \\
\hline Initial solid concentration & $20 \%$ & \\
\hline Residence time & 1.5 days & \\
\hline Nutrients & $0.33 \mathrm{~g} / \mathrm{l}$ broth & \\
\hline
\end{tabular}

processes; the steam turbine turns a generator that produces electricity for the plant. The $\mathrm{LHV}_{\text {(wet basis) }}$ of the combined feed to the combustor $^{1}$ (lignin, solid residues, evaporator syrup, and biogas) is around $10 \mathrm{MJ} / \mathrm{kg}$, and the steam process required in bioethanol production plant accounts for around 51\% of the combined feed energy (Aden et al., 2002). Total electricity generation is $\sim 15.4 \%$ of the feed energy input (residues from bioethanol and biodiesel process).

The transportation of the bioethanol from the plant to the refinery and from the refinery to the gas station is assumed to be performed by 28-t trucks for an average road transport distance of 800 and $200 \mathrm{~km}$, respectively.

\subsection{Allocation methods}

Palm based Biorefinery consists of variety of intermediates in the process chains to yield a large number of products, and therefore, it demands an allocation of the upstream flows to the products. The allocation methods can significantly affect the outcome of the analysis (Singh et al., 2010). Various allocation methods are discussed by other authors (Gnansounou et al., 2009; Singh et al., 2010; Cherubini and Strømman, 2011), nevertheless, there is no single methodology recognized as the best allocation practice, and the choice of the allocation approach for multiprocessing systems like biorefinery is still debatable (Cherubini and Strømman, 2011).

In this study, the energy content of the net products is used as the allocation method to distribute the burdens of upstream flows to the intermediates and final products as shown in Fig. 2.

The low heating values of products are $26.7 \mathrm{MJ} / \mathrm{kg}$ for bioethanol, $37.9 \mathrm{MJ} / \mathrm{kg}$ for biodiesel, $13 \mathrm{MJ} / \mathrm{kg}$ for crude glycerin, and $17 \mathrm{MJ} / \mathrm{kg}$ for crude palm kernel oil (Pleanjai and Gheewala, 2009). Application of energy allocation can lack a logical support, if some of the products (e.g., crude palm kernel cake in this study) are not used for their energy content (Gnansounou et al., 2009). Crude palm kernel cake contains $14.6-16 \%$ crude protein, useful for fattening cattle (Chin, 2003) as an example, therefore, the average metabolism energy value of $\sim 12.1 \mathrm{MJ} / \mathrm{kg}$ (Chin, 2003) is used to allocate the upstream emissions to this product.

\footnotetext{
${ }^{1}$ Solid feed is pumped into the Pneumapress pressure filter and by forcing compressed air ( $9.5 \mathrm{~atm}$ ); it is dewatered to a level of $\sim 45 \%$ moisture content (for residues from bioethanol process with $\sim 10 \mathrm{MJ} / \mathrm{kg} \mathrm{LHV}_{\text {wet }}-$ combined feed) (Aden et al., 2002), and $\sim 10-12 \%$ moisture content (for residues from biodiesel process with

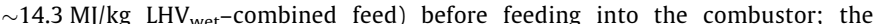
electricity consumption for this drying system is around $3.2 \%$ of the total electricity consumption adopted from (Aden et al., 2002).
}

\subsection{Well-to-wheel GHG emissions}

Biodiesel-diesel blends have shown almost the same combustion stages as the diesel fuels leading to small variations in thermal efficiency. Nevertheless, depending on the engine types, loads, operation modes and fuel blends, palm-based biodiesel has around 1-9\% less power compared to that of fossil-based diesel fuel, which leads to higher fuel consumption (Lapuerta et al., 2008). For a $20 \%$ biodiesel blend (20\% biodiesel and $80 \%$ fossil-diesel in volume), the loss of power at medium to full load could be around 1-3.3\% (Lapuerta et al., 2008), averagely $2 \%$.

In 2008, the Brazilian average fuel efficiency of gasoline for the new passenger car was $7.371 / 100 \mathrm{~km}(13.72 \mathrm{~km} / \mathrm{l})$, which represents an actual $0.4 \%$ annual deterioration (François and Lew, 2011) as compared with the gasoline fuel efficiency in $2005^{2}$. The assumed estimate of the fuel efficiency of gasoline in 2012 is $7.48 \mathrm{l} / 100 \mathrm{~km}(13.37 \mathrm{~km} / \mathrm{l})$. For the $20 \%$ ethanol fuel blended with gasoline fuel, the reduction in the low heating value could be $\sim 8 \%$ and the increased fuel consumption are around 6\% (Schifter et al., 2011). According to the US Department of Energy (USDE), 11 of diesel has $113 \%$ of energy of 11 of gasoline, and diesel engines are 30-35\% more energy-efficient than the same size gasoline engines. Accordingly, the fuel efficiency of diesel is estimated to be $5.24 \mathrm{l} /$ $100 \mathrm{~km}(19.10 \mathrm{~km} / \mathrm{l})$.

Considering the above discussions, the fuel economies of B20 and E20 are $5.34 \mathrm{l} / 100 \mathrm{~km} \quad(18.72 \mathrm{~km} / \mathrm{l})$ and $7.96 \mathrm{l} / 100 \mathrm{~km}$ $(12.57 \mathrm{~km} / \mathrm{l})$, respectively.

The analysis of well-to-wheel net GHG emissions of biofuel is done by assuming that the fuel economies of gasoline and fossildiesel in the fuel blends are equal to those of standard fuels, and that the difference is mainly due to the presence of biofuel in the fuel blends (Gnansounou et al., 2009). This study has adopted the methodology developed by Gnansounou et al. (2009) to estimate the fuel efficiency, and consequently the well-to-wheel GHG emissions of the biofuel blends for $100 \mathrm{~km}$ traveled distance as presented in Eqs. (3) and (4).

$$
\begin{aligned}
& \text { Fuelefficiency } y_{\text {bifuel }} \\
& \text { biofuelblendfactor } \times \text { fuelefficiency }_{\text {fuellbend }} \times 100
\end{aligned}
$$

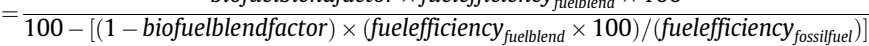

\footnotetext{
2 This is most likely due to the production shift from very small vehicles to medium size ones, but the fuel efficiency is still better than the average global fuel efficiency in 2008 ( 7.67 l gasoline-eq/100 km) with an actual annual improvement of $1.6 \%$.
} 


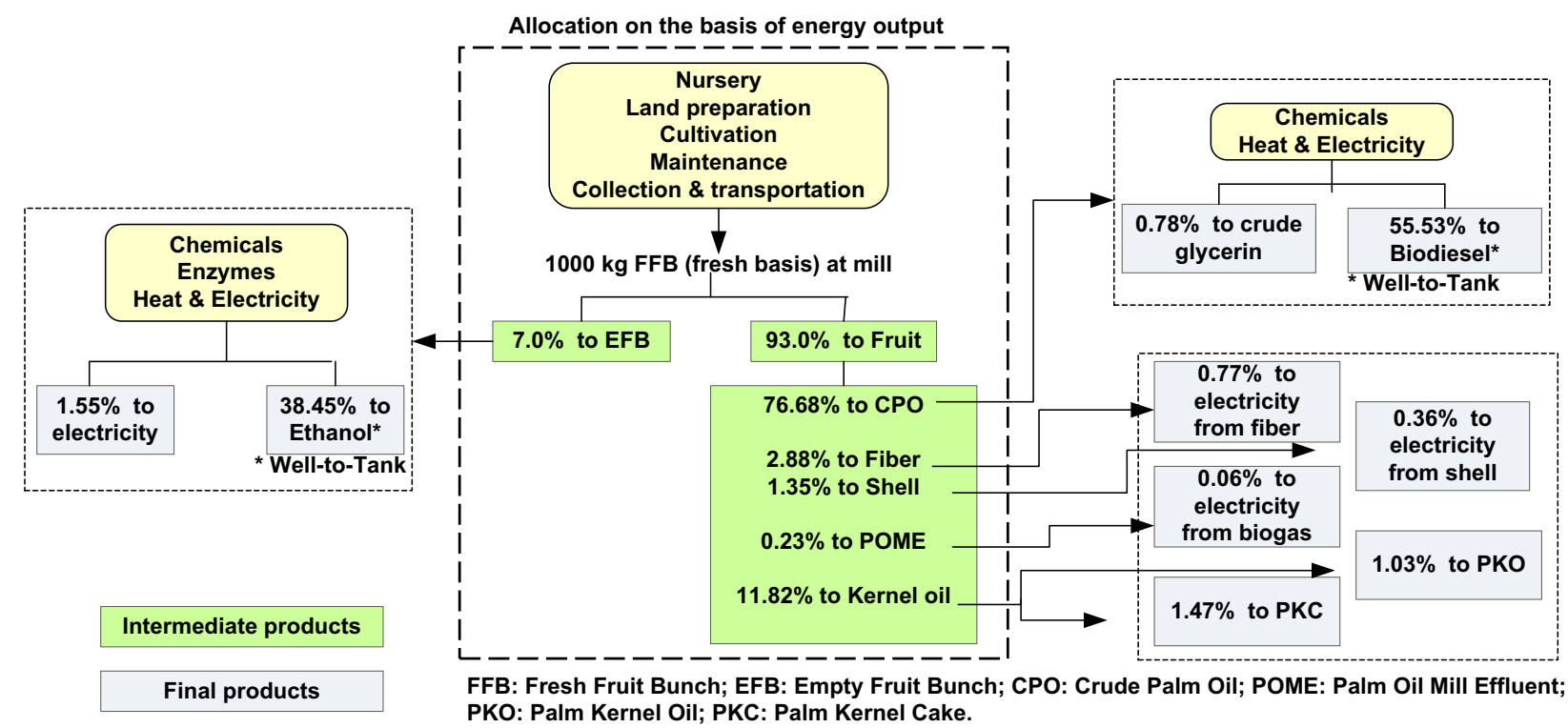

Fig. 2. Allocation of the upstream emissions to the products of palm-based biorefinery system.

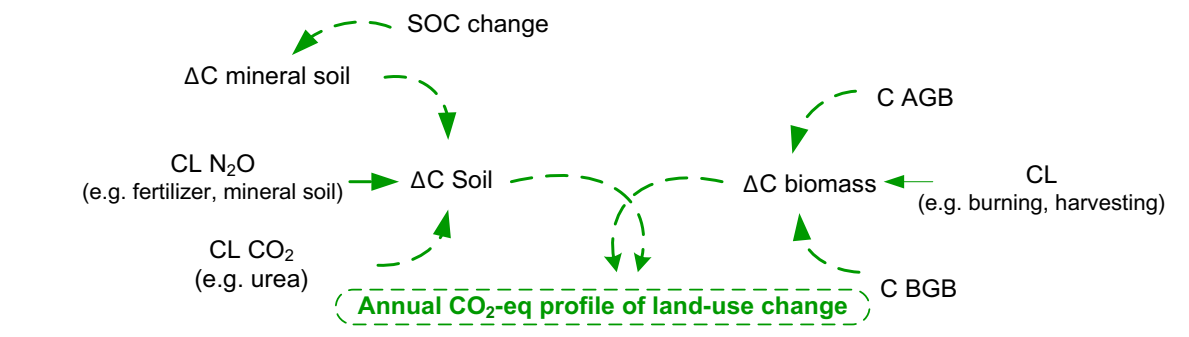

$\triangle \mathrm{C}$ : Carbon change; SOC: Soil Organic Carbon ( Ref. Partially degraded grass land); C AGB: Carbon of Above Ground Biomass; C BGB: Carbon of Below Ground Biomass; CL: Carbon loss.

Fig. 3. Simplified diagram of carbon stock changes by direct land-use change.

Table 5

Estimates of the oil palm biomass.

\begin{tabular}{|c|c|c|c|}
\hline Vegetation & Value & Ref. & Remark \\
\hline Carbon content of grasses-t C/ha & $8.1^{\mathrm{a}}$ & (IPCC, 2006) & Default ratio of $50 \%$ carbon content ${ }^{b}$ \\
\hline Palm trunks at tree felling-t dry/ha & 75.5 & BFPIC $^{\mathrm{c}}$ & \\
\hline Pruned fronds-t dry/ha/yr & $10.4^{\mathrm{d}}$ & BFPIC \& (Frazào, 2012) & 3-year old onwards \\
\hline Fronds at tree felling-t dry/ha & 14.4 & BFPIC & \\
\hline Root-t dry/ha & $16^{\mathrm{e}}$ & (Khalid et al., 1999) & $\sim 16 \%$ of above and below ground biomass \\
\hline
\end{tabular}

a $2.91 \mathrm{t} \mathrm{C/ha} \mathrm{AGB} \mathrm{and} 5.16 \mathrm{t}$ C/ha BGB.

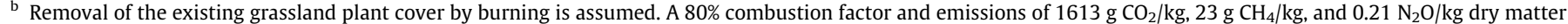
burnt (IPCC, 2006).

c Beijing Forestry and Parks Department of International Co-operation. Oil palm biomass.

d During the crop phase, fronds are pruned and pilled between every two rows of palm trees (Frazào, 2012). Though, it is not accounted because of a complete decomposition at completion of the 25-year economic life span (Germer and Sauerborn, 2008).

e At the end of economic life time.

$G H G_{\text {biofuel-WtW }}=G H G_{\text {biofuel-WtT }} \times$ Fuel efficiency $_{\text {biofuel }}$

In Eq. (3), Fuel efficiency biofuel is the estimated fuel efficiency of bioethanol and biodiesel in $1 / 100 \mathrm{~km}$, fuel blend factor is $20 \%$ for B20 and E20, Fuel efficiency fuelblend $\times 100$ is the blended fuel consumption for a travel of $100 \mathrm{~km}$ i.e., 5.341 for B20 and 7.961 for E20, '100' is the assumed $\mathrm{km}$ traveled distance in this study, and Fuel efficiency fossilfuel is the fuel efficiency of diesel and gasoline in $1 / 100 \mathrm{~km}$ as explained in the text.

In Eq. (4), GHG biofuel-wtw is the well-to-wheel GHG emission of the biofuels (i.e., bioethanol and biodiesel) for a $100 \mathrm{~km}$ distance, GHG biofuel-WtT is the estimated GHG emission of biofuel produced in the palm-based biorefinery and transported to the petroleum refinery and then to the station in $\mathrm{kg} \mathrm{CO}_{2}$-eq/1 biofuel, and Fuel efficiency biofuel is in $1 / 100 \mathrm{~km}$ obtained from Eq. (3).

The life-cycle well-to-wheel GHG emissions of conventional gasoline and fossil diesel obtained from Ecoinvent are $0.21 \mathrm{~kg}$ $\mathrm{CO}_{2}$-eq $/ \mathrm{km}$ and $0.24 \mathrm{~kg} \mathrm{CO}$-eq $/ \mathrm{km}$, respectively.

\subsection{Direct land-use change and carbon emissions}

The land-use change refers to the change in the status of the land-use resulting in direct and indirect impacts, e.g., displacement 


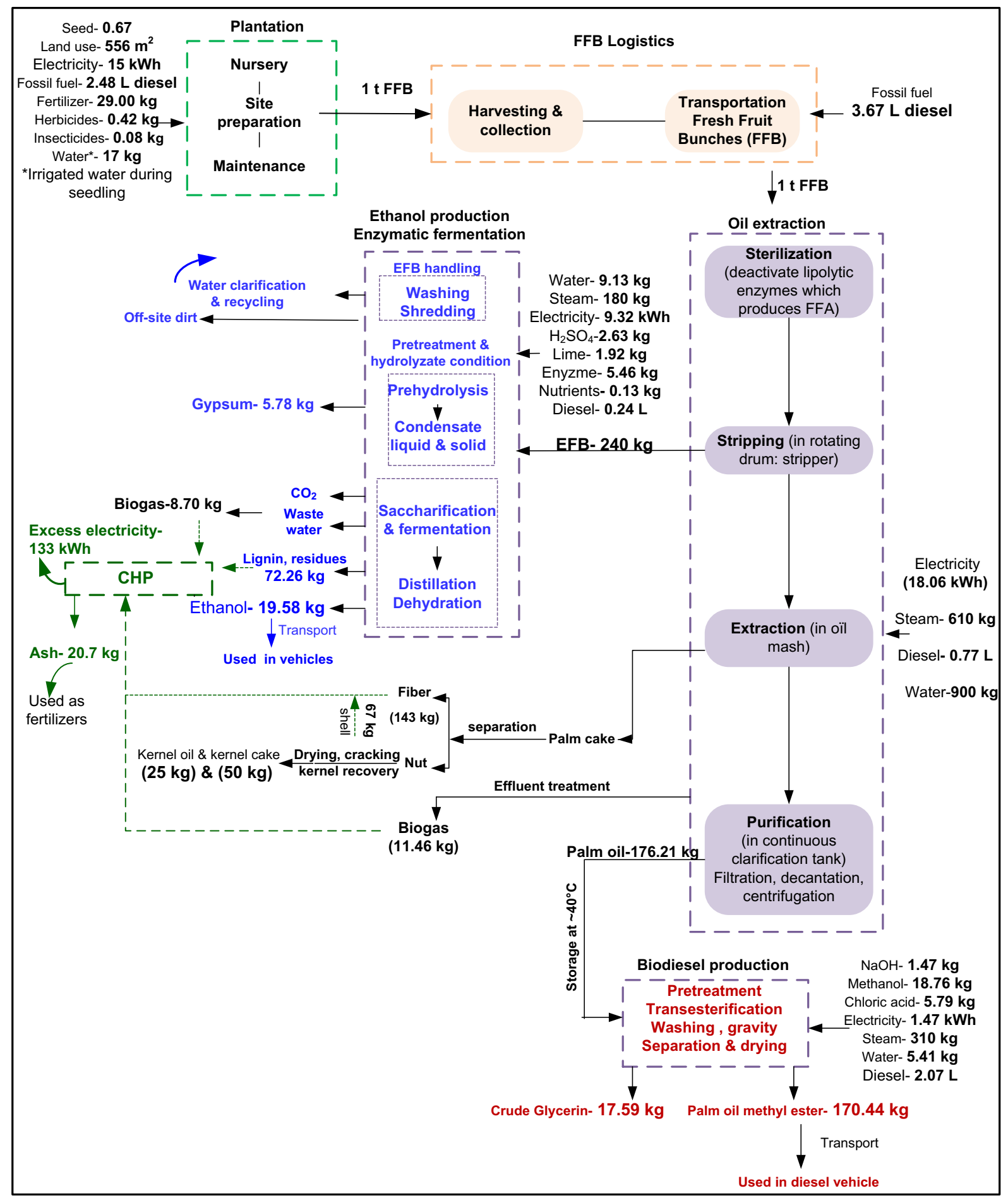

Functional unit is 1 t FFB (wet), and the flows are determined for $\sim 2$ million t FFB produced in $\sim 110,000$ ha of oil palm farm.

Fig. 4. Main inflows and outflows of a prospective palm-based refinery.

of previous land-use to other locations as is the case for soybean cultivation in Brazil to displace pasture, leading to deforestation elsewhere. The consequence from carbon stock changes caused by direct land-use change is included in the calculation of GHG emission through the methodology provided in the 'Guideline for National Greenhouse Gas Inventories' by the 'Intergovernmental Panel on Climate Change (IPCC)' (IPCC, 2006), which is summarized in Fig. 3 and are on the basis of Eqs. (A1)-(A7) in Appendix A. The soil organic carbon and changes of above and below ground biomass and the resulting greenhouse gas fluxes with respect to oil palm plantation are assessed. This study has counted neither the nitrate and ammonia emissions from fertilizer nor the nitrogen emissions from the crop residues and nitrogen uptake by the plant.

Accounting period for the land-use is the same as the commercial life span of oil palm which is 25 years. The FFB yield is $18 \mathrm{t} \mathrm{FFB/}$ ha of land cultivated (see Section 2.1). The IPCC defaults values or those from the published literatures for Brazilian situation are used (Appendix A). The tropical wet climate zone, low to medium clay 

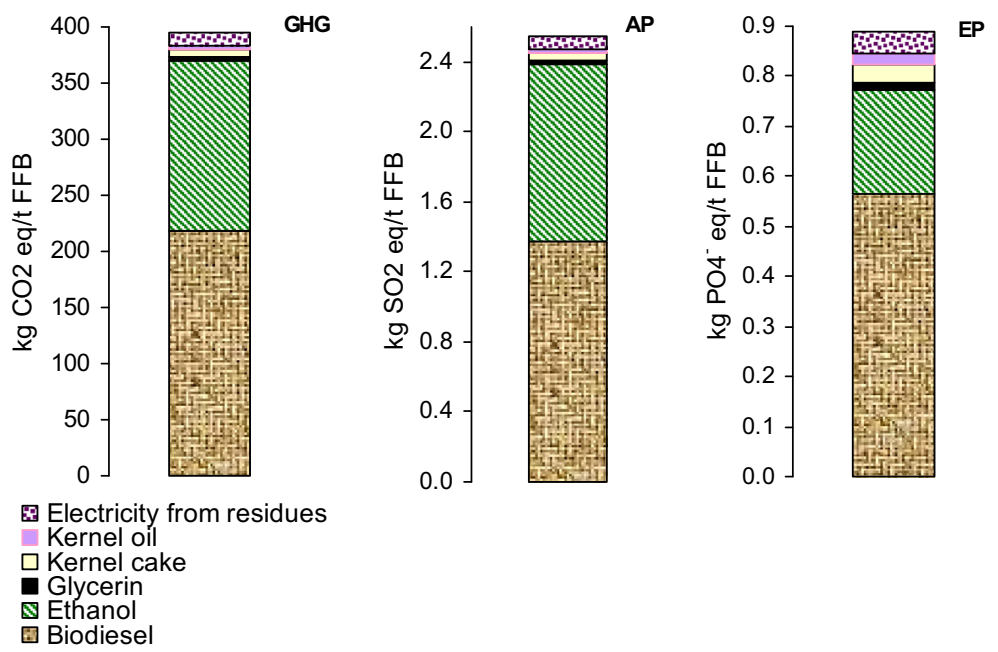

Fig. 5. Allocated environmental impacts to the products of a palm-based biorefinery.

soil type, and no tillage management are considered. Main gases included in the calculation of GHG emissions are $\mathrm{CO}_{2}, \mathrm{CH}_{4}$ and $\mathrm{N}_{2} \mathrm{O}$ and the carbon dioxide equivalent emission factors of 25 and 298 are used for $\mathrm{CH}_{4}$ and $\mathrm{N}_{2} \mathrm{O}$ (IPCC, 2007). The major information of the carbon content of the biomass is provided in Table 5 . Unless otherwise specified, the default values of IPCC (IPCC, 2006) are used.

\section{Results and discussion}

The estimated inflows-outflows for the use of $1 \mathrm{t}$ FFB in the palm-based biorefinery in Fig. 4, scheme the quantities of each product, co-product, fossil fuels, and materials including enzymes, chemicals, nutrients used for the whole process.

The main inputs for the FFB production are fertilizers $(13 \% \mathrm{~N}$ $33 \% \mathrm{P}, 38 \% \mathrm{~K}$, and the rest $\mathrm{Mg}$ and Borax), and diesel-fuel (28.9\% for plantation, $9.8 \%$ for the transportation of chemicals, and $61.2 \%$ for the FFB's transportation to the plant). The nutritious values of EFB could displace $20 \%$ of $\mathrm{N}(0.63 \mathrm{~kg} / \mathrm{t} \mathrm{FFB}), 0.5 \%$ of $\mathrm{P}$ $(0.05 \mathrm{~kg} / \mathrm{t} \mathrm{FFB}), 18 \%$ of $\mathrm{K}(1.53 \mathrm{~kg} / \mathrm{t} \mathrm{FFB})$, and $4 \%$ of $\mathrm{Mg}(0.10 \mathrm{~kg} / \mathrm{t}$ FFB) if recycled into oil palm fields. However, the advantage of bioethanol and excess electricity generations from EFB is noticeable as discussed later in this section.

In the milling process about 55-77\% of energy generated from combustion of fibers and shells can be used for the own plant consumption (Patthanaissaranukool et al., 2013). This study shows that $\sim 66 \%$ of the low heating value of the combined feed (fiber, shell, and biogas) is used for the process steam of milling and biodiesel production, and $\sim 51 \%$ of low heating value of lignin, evaporator syrup, solid residues, and biogas is used for the process steam of ethanol process. From the total electricity generated in the refinery plant, $\sim 22 \%$ is used for the own use of plant. There is a net electricity credit of $133 \mathrm{kWh} / \mathrm{t}$ FFB (80\% from residues in the milling process and $20 \%$ from redisues in the ethanol process).

In the biorefinery plant, around 2 million tons of FFB can be converted to $\sim 39,000$ t bioethanol, $\sim 340,000$ t biodiesel, $\sim 268 \mathrm{GWh}$ net electricity, and considerable amount of other co-products as shown in Fig. 1. The net energy balance (the difference between renewable energy output and direct non-renewable energy input) would be $8127 \mathrm{MJ} / \mathrm{t}$ FFB or $146 \mathrm{GJ} / \mathrm{ha}$.

The assigned life-cycle environmental impact namely well-totank GHG emissions, Eutrophication potential (EP), and Acidification potential (AP) is shown in Fig. 5.

Three important activities involved in the biorefinery plant are fertilizers' applications, chemical uses, and transportations. The contribution of each of these activities to the AP, EP, and GHG emissions (not shown in the figure) would be $19 \%, 48 \%$, and $18 \%$ for fertilizer, $8 \%, 6 \%$, and $13 \%$ for chemicals, and $73 \%, 46 \%$, and $69 \%$ for transportation, respectively.

Evidently, transportation of the agricultural phase and industrial phase is the main contributor to the GHG emission (95\% from industrial phase and 5\% from agricultural phase) and AP impacts (93\% from industrial phase and 7\% from agricultural phase). Thus, transportation activities need more attention from decision-makers' point of view to reduce the GHG emissions and acidification burdens of a palm-based biorefinery in future ${ }^{3}$.

The overall life-cycle well-to-tank GHG emission of the biorefinery system is $394.3 \mathrm{~kg} \mathrm{CO}$-eq/ $\mathrm{t}_{\mathrm{FFB}}$ corresponding to $17.4 \mathrm{~g}$ $\mathrm{CO}_{2}$-eq/MJ $\mathrm{M}_{\text {ethanol }}\left(0.37 \mathrm{~kg} \mathrm{CO}{ }_{2}\right.$-eq $\left./ \mathrm{l}_{\text {ethanol }}\right), 25.1 \mathrm{~g} \mathrm{CO}$-eq/MJ $/ \mathrm{MJiodiesel}_{\text {b }}$ $\left(0.84 \mathrm{~kg} / \mathrm{CO}_{2}-\mathrm{eq} / \mathrm{l}_{\text {biodiesel }}\right)$, and $2.7 \mathrm{~g} \mathrm{CO}$-eq $/ \mathrm{MJ}_{\text {other energy. }}$ In comparison to soybean-based biodiesel and sugarcane-based bioetha$\mathrm{nol}$ in Brazil, the emission is $30.7 \mathrm{~g} \mathrm{CO}_{2}$-eq/ $/ \mathrm{MJ}_{\text {biodesel }}$ including an allocation of around $64 \%$ to soy-meal in crushing phase (Cavalett and Ortega, 2010), and a range of 24.3-27.5 $\mathrm{g} \mathrm{CO}_{2}$-eq/MJ $\mathrm{J}_{\text {bioethanol }}$ including $5.4 \%$ credit to the excess electricity sold to the grid (Walter et al., 2011).

Considering the adopted method in Section 2.7, the fuel efficiency of bioethanol and biodiesel would be $10.68 \mathrm{l} / 100 \mathrm{~km}$ and $5.82 \mathrm{l} / 100 \mathrm{~km}$, respectively. In other words, about $1.43 \mathrm{l}$ of bioethanol and $1.11 \mathrm{l}$ of biodiesel can produce similar fuel efficiency to $1 \mathrm{l}$ of gasoline fuel and 11 of fossil-diesel fuel to travel the same distance. Based on this substitution factor, and well-to-wheel GHG emission of biofuels through Eq. (4), the environmental advantages with respect to GHG emission reductions would be $76.9 \%$ for biodiesel and $83.7 \%$ for bioethanol compared to fossil diesel and gasoline, respectively. This study has performed a well-to-wheel GHG emission of bioethanol and biodiesel assuming a deterioration fuel efficiency of B20 and E20 as discussed in Section 2.7. Some studies have reported an improved or equal fuel efficiency of lower rates of the fuel-blends in Europe (Gnansounou et al., 2009) and similar rates in Brazil (Walter et al., 2011). Assuming equal fuel efficiency to the conventional fossil fuels for the fuel blends of B20 and E20, the GHG emission reduction increases to $79.3 \%$ for biodiesel and 88.6\% for bioethanol.

This paper has also focused on the major direct GHG sinks/ emissions during land-use change of degraded grass land to oil

\footnotetext{
${ }^{3}$ In Brazil, the biofuel mixing is mainly done by Petrobras refinery plant, with a branch in Belém (capital of the Pará State). The privilege of transporting the biofuel to the refinery plant via river could decrease the GHG emissions in future.
} 
palm plantation. The result indicates an annual credit of $\sim 0.1 \mathrm{t} \mathrm{C/t}$ FFB corresponding to $0.4 \mathrm{t} \mathrm{CO}_{2}$-eq/t FFB. In other words, under the management system and for the soil type and ecological climate condition of Pará State, converting the grass lands which are created by deforestation in the past to oil palm plantation can annually sequester $7.5 \mathrm{t} \mathrm{CO}_{2}$-eq/ha of land. Major $\mathrm{CO}_{2}$ fluxes during land-use change are from fertilizers as $\mathrm{N}_{2} \mathrm{O}-\mathrm{N}\left(6.2 \mathrm{~kg} \mathrm{CO} \mathrm{CO}_{2}-\mathrm{eq} / \mathrm{t}\right.$ FFB), from mineral soil as $\mathrm{N}_{2} \mathrm{O}-\mathrm{N}(6.6 \mathrm{~kg} / \mathrm{t} \mathrm{FFB})$, and from urea (3.0 kg CO Ceq $_{2} \mathrm{t} \mathrm{FFB).} \mathrm{For} \mathrm{the} \mathrm{25-year} \mathrm{commercial} \mathrm{life} \mathrm{span} \mathrm{of} \mathrm{the}$ oil palm, the advantage of grassland rehabilitation by oil palm plantation is the removal of $\sim 188 \mathrm{t} \mathrm{CO}_{2} /$ ha from the atmosphere.

Furthermore, one hectare of land cultivated by oil palm can provide $\sim 523 \mathrm{MJ}$ of ethanol, $6453 \mathrm{MJ}$ of biodiesel, and $\sim 1737 \mathrm{MJ}$ of non-fuel products. Focusing only on the biofuel, establishing a palm-based biorefinery can displace or reduce the agricultural land which could otherwise be used for generation bioethanol from sugarcane and biodiesel from soybean in Brazil. The average ethanol yield from sugarcane and the corresponding land productivity in Brazil is $86.3 \mathrm{l} / \mathrm{t}$ cane $(1818 \mathrm{MJ})$, and $81.1 \mathrm{t}$ cane/ha, respectively (Macedo et al., 2008). Production of 11 biodiesel from soybean demands $5.22 \mathrm{~m}^{2}$ of land (Cavalett and Ortega, 2010), i.e., 1916 l/ha. Therefore, one hectare of land cultivated by oil palm can displace $\sim 0.064$ ha of land cultivated by sugarcane for ethanol production, and $\sim 1.82$ ha of land cultivated by soybean for biodiesel production, although soybean generates other co-products such as soymeals.

\section{Conclusions}

The life cycle assessment of a prospective palm-based biorefinery in this study has quantified the impacts of acidification and eutrophication potentials, GHG emissions as well as the GHG consequences of direct land-use change of degraded pasture land to oil palm cultivation in Pará State. For the 25-year commercial life span of oil palm, around $188 \mathrm{t} \mathrm{CO}_{2}$ /ha can be sequestered from atmosphere. Depending on the fuel efficiency of fuel blends, the well-to-wheel life-cycle analysis of biodiesel and bioethanol as compared to the conventional fossil fuels shows a positive GHG reduction of $76.9-79.3 \%$ and $83.7-88.6 \%$, respectively.

\section{Acknowledgements}

The authors acknowledge the financial support of the VALE International SA and the Swiss State Secretariat for Education and Research.

\section{Appendix A. Supplementary data}

Supplementary data associated with this article can be found, in the online version, at http://dx.doi.org/10.1016/j.biortech.2013. 07.100 .

\section{References}

Aden, A., Ruth, M., Ibsen, K., Jechura, J., Neeves, K., Sheehan, J. et al., 2002. NREL. Lignocellulosic biomass to ethanol process design and economics utilizing cocurrent dilute acid prehydrolysis and enzymatic hydrolysis for corn stover. In. NREL/TP-510-32438.

Baharuddin, A.S., Hock, L.S., Yusof, M.Z.M., Rahman, N.A.A., Shah, U.K.M.S., Hassan, M.A., et al., 2010. Effects of palm oil mill elluent (POME) anaerobic sludge from $500 \mathrm{~m}^{3}$ of closed anaerobic methane digested tank on pressed-shredded empty fruit bunch (EFB) composting process. Afr. J. Biotechnol. 9, 2427-2436.

Cavalett, O.V., Ortega, E., 2010. Integrated environmental assessment of biodiesel production from soybean in Brazil. J. Clean Prod. 18, 55-70.

Cherubini, F., Strømman, A.H., 2011. Life cycle assessment of bioenergy systems: state of the art and future challenges. Bioresour. Technol. 102, 437-451.
Chew, T.L., Bhatia, S., 2008. Catalytic processes towards the production of biofuels in a palm oil and oil palm biomass-based biorefinery. Bioresour. Technol. 99, 7911-7922.

Chiesa, S., 2012. Bioethanol production from oil palm empty fruit bunches: a comparison among different pretreatment options. PhD thesis. In Gr-GR. Lausanne: EPFL.

Chin, F.Y., 2003. Palm kernel cake (CPK) as a supplement for fattening and dairy cattle in Malaysia. In: FAO-7th meeting of regional working group on grazing and feed resources. Forege development in Southeast Asia: strategies and impacts.

Delivand, M.K., Barz, M., Gheewala, S.H., 2011. Logistics cost analysis of rice straw for biomass power generation in Thailand. Energy 36, 1435-1441.

FitzPatrick, M., Champagne, P., Cunningham, M.F., Whitney, R.A., 2010. A biorefinery processing perspective: treatment of lignocellulosic materials for the production of value-added products. Bioresour. Technol. 101, 8915-8922.

François, C., Lew, F., 2011. OECD/IEA. International comparison of light-duty vehicle fuel economy and related characteristics. In, Global Fuel Economy Initiative (GFEI), International Energy Agency (IEA), FIA foundation, UBEP International Transport Forum.

Frazào, L.A., 2012. Greenhouse gas emissions and soil carbon dynamics in the Brazilian oil plam production. PhD. thesis. In College of Agriculture "Luiz de Queiroz". Sào Paulo: University of Sào Paulo.

Germer, J., Sauerborn, J., 2008. Estimation of the impact of oil palm plantation establishment on greenhouse gas balance. Environ. Dev. Sustain. 10, 697-719.

Gnansounou, E., Dauriat, A., Villegas, J., Panichelli, L., 2009. Life cycle assessment of biofuels: energy and greenhouse gas balances. Bioresour. Technol. 100, 49194930.

Haas, M.J., McAloon, A.J., Yee, W.C., Foglia, T.A., 2006. A process model to estimate biodiesel production costs. Bioresour. Technol. 97, 671-678.

Harding, K.G., Dennis, J.S., Von Blottnitz, H., Harrison, S.T.L., 2008. A life-cycle comparison between inorganic and biological catalysis for the production of biodiesel. J. Clean Prod. 16, 1368-1378.

Hassan, M.N.A., Jaramillo, P., Griffin, W.M., 2011. Life cycle GHG emissions from Malaysian oil palm bioenergy development: the impact on transportation sector's energy security. Energy Policy 39, 2615-2625.

IPCC, 2006. Intergovernmental panel on climate change. Guidelines for National Greenhouse Gas Inventories, Volume 4, Agriculture, Forestry and Other landuse.

IPCC, 2007. IPCC fourth assessment report: climate change. http://www.ipcc.ch/ publications_and_data/ar4/wg1/en/ch2s2-10-2.html.

Jung, Y.H., Kim, I.J., Kim, H.K., Kim, K.H., 2013. Dilute acid pretreatment of lignocellulose for whole slurry ethanol fermentation. Bioresour. Technol. 132, 109-114.

Khalid, H., Zin, Z.Z., Anderson, J.M., 1999. Qualification of oil palm biomass and nutrient value in a mature plantation. II Below-ground biomass. J. Oil Palm Res. $11,63-71$.

Kim, S., Dale, B.E., 2005. Life cycle assessment of various cropping systems utilized for producing biofuels: bioethanol and biodiesel. Biomass Bioenergy 29, 426439.

Lapuerta, M.N., Armas, O., Rodrinquez-Fermántez, J., 2008. Effect of biodiesel fuels on diesel engine emissions. Prog. Energy Combust. Sci. 34, 198-223.

Liang, S., Xu, M., Zhang, T., 2013. Life cycle assessment of biodiesel production in China. Bioresour. Technol. 129, 72-77.

Luo, L., van der Voet, E., Huppes, G., 2010. Biorefining of lignocellulosic feedstock technical, economic and environmental considerations. Bioresour. Technol. 101, 5023-5032.

Macedo, I.C., Seabra, J.E.A., Silva, J.E.A.R., 2008. Green house gas emissions in the production and use of ethanol from sugarcane in Brazil: the 2005/2006 averages and a prediction for 2020. Biomass Bioenergy 32, 582-595.

Nielsen, P.H., Oxenbøll, K.M., Wenzel, H., 2007. Cradle-to-gate environmental assessment of enzyme products produced industrially in Denmark by Novaozame A/S. Int. J. LCA 12 (6), 432-438.

Nwoko, C.O., Ogunyemi, S., 2010. Evaluation of palm oil mill effluent to maize (Zea mays. L) crop: yield, tissue nutrient content and residual soil chemical properties. Aust. J. Crop. Sci. 4, 16-22.

Patthanaissaranukool, W., Polprasert, C., Englande Jr, A.J., 2013. Potential reduction of carbon emissions from crude palm oil production based on energy and carbon balances. Appl. Energy 102, 710-717.

Pleanjai, S., Gheewala, S.H., 2009. Full chain energy analysis of biodiesel production from palm oil in Thailand. Appl. Energy 86 (Suppl. 1), S209-S214.

Queiroz, A.G., França, L., Ponte, M.X., 2012. The life cycle assessment of biodiesel from palm oil ("dendê") in the Amazon. Biomass Bioenergy 36, 50-59.

Schifter, I., Diaz, L., Rodriguez, R., Gómez, J.P., Gonzalez, U., 2011. Combustion and emissions behavior for ethanol-gasoline blends in a single cylinder engine. Fue 90, 3586-3592.

Singh, A., Pant, D., Korres, N.E., Nizami, A.S., Prasad, S., Murphy, J.D., 2010. Key issues in life cycle assessment of ethanol production from lignocellulosic biomass: challenges and perspectives. Bioresour. Technol. 101, 5003-5012.

Walter, A., Dolzan, P., Quilodrán, O., de Oliveira, J.G., da Silva, C., Piacente, F. Segerstedt, A., 2011. Sustainability assessment of bio-ethanol production in Brazil considering land-use change, GHG emissions and socio-economic aspects. Energy Policy 39, 5703-5716.

Wei, L., Pordesimo, L.O., Haryanto, A., Wooten, J., 2011. Co-gasification of hardwood chips and crude glycerol in a pilot scale downdraft gasifier. Bioresour. Technol. $102,6266-6272$. 